\title{
PROPOSALS OF SPHINGOBACTERIUM FAECIUM SP. NOV., SPHINGOBACTERIUM PISCIUM SP. NOV., SPHINGOBACTERIUM HEPARINUM COMB. NOV., SPHINGOBACTERIUM THALPOPHILUM COMB. NOV. AND TWO GENOSPECIES OF THE GENUS SPHINGOBACTERIUM, AND SYNONYMY OF FLAVOBACTERIUM YABUUCHIAE AND SPHINGOBACTERIUM SPIRITIVORUM
}

\author{
MARIKO TAKEUCHI* AND AKIRA YOKOTA \\ Institute for Fermentation, Osaka, Yodogawa-ku, Osaka 532, Japan
}

(Received June 4, 1992)

\begin{abstract}
Seventeen strains of Cytophaga, Flavobacterium and Actinobacillus species were taxonomically characterized. DNA base composition of these strains ranged from 39.0 to $42.3 \mathrm{~mol} \%$, and the menaquinone system was MK-7. All the strains contained sphingolipids with long-chain bases, which are characteristic of the genus Sphingobacterium. Based on their chemotaxonomic and physiological characteristics together with DNA/ DNA hybridization studies, we propose two new species and two new combinations, Sphingobacterium faecium sp. nov., Sphingobacterium piscium sp. nov., Sphingobacterium heparinum comb. nov., Sphingobacterium thalpophilum comb. nov. and two genospecies of the genus Sphingobacterium. Flavobacterium yabuuchiae was found to be a synonym of Sphingobacterium spiritivorum.
\end{abstract}

The genus Sphingobacterium was established by Yabuuchi et al. (30) for the three species, Sphingobacterium spiritivorum, Sphingobacterium multivorum and Sphingobacterium mizutae. Recently, new species, Sphingobacterium antarcticus (23) has been reported. Sphingobacterium species are characterized by their low guanine-plus-cytosine $(\mathrm{G}+\mathrm{C})$ contents of DNA (approximately 39 to $42 \mathrm{~mol} \%$ ), isoprenoid quinones with MK-7 and sphingolipids with long-chain base dihydrosphingosin.

However, Holmes et al. (8) proposed that $S$. spiritivorum and $S$. mizutae should

* Address reprint requests to: Mrs. Mariko Takeuchi, Institute for Fermentation, Osaka, 17-85, Juso-honmachi 2-chome, Yodogawa-ku, Osaka 532, Japan. 
be retained in the genus Flavobacterium as Flavobacterium spiritivorum and Flavobacterium mizutaii, respectively. Besides these 2 species, 11 species, namely $F$. aquatile, $F$. breve, $F$. balustinum, $F$. meningosepticum, $F$. odoratum, $F$. thermophilum, F. branchiophila, F. gleum, F. indologenes, F. thalpophilum and F. yabuuchiae are recognized in the genus Flavobacterium $(3,5-8,23,28,30)$. Among the species, $F$. thermophilum should be excluded from the genus Flavobacterium on the basis of its high $\mathrm{G}+\mathrm{C}$ content of DNA (62 mol\%).

On the other hand, Cytophaga was established in 1929 by Winogradsky (29) for aerobic, cellulose-decomposing, water-insoluble pigment-producing organisms with a peculiar gliding motility. In Bergey's Manual of Systematic Bacteriology, Vol. 3 (21), Cytophaga species were reported to have low $\mathrm{G}+\mathrm{C}$ contents from 30 to $45 \mathrm{~mol} \%$ (many strains occurring around $35 \mathrm{~mol} \%$ ), the quinone system MK-6 or MK-7, and cellular fatty acids consist of branched-chain non-polar and hydroxy acids. However, the genera Cytophaga and Flavobacterium share chemotaxonomic characteristics, and the only criterion for differentiating these genera is gliding motility.

Cytophaga heparina is an organism described by Payza and Korn (20) as Flavobacterium heparinum and later re-classified as $C$. heparina by Christensen (2) for the reason that it had been shown to glide. On the other hand, "Cytophaga keratolytica" was first described under the name "Flavobacterium keratolyticus" by Kitamikado and Ito (12) and then re-classified as a species of the genus Cytophaga by Imai (10), despite the absence of obvious gliding movement. In Bergey's Manual of Systematic Bacteriology, Vol. 3(21), it is suggested that these two species be excluded from the genus Cytophaga for the reason that they do not glide. Therefore, their taxonomic positions have remained uncertain (26).

Phenovar "4-5" strains of C. heparina, Flavobacterium ferrugineum, "Flavobacterium sewanense" and Flavobacterium sp. reported by Oyaizu et al. $(17,18)$, and Actinobacillus sp. IFO 13310 in the IFO culture collection, a keratan sulfatedegrading bacterium $(12,16)$, were found to be strains of the FlavobacteriumCytophaga complex on the basis of $\mathrm{G}+\mathrm{C}$ contents of DNA, quinone system, and cellular fatty acid composition. Furthermore, the presence of sphingolipid in the cells suggested that these might be strains of the genus Sphingobacterium.

In this paper, we examined the phenotypic and chemotaxonomic characteristics of 17 strains of named Flavobacterium, Cytophaga or Actinobacillus, and compared them with those of previously-reported species of the genus Sphingobacterium, and we propose two new species, two new combinations and two genospecies of the genus Sphingobacterium on the basis of chemotaxonomic, phenotypic and DNA/DNA hybridization studies.

\section{MATERIALS AND METHODS}

Microorganisms and culture conditions. The strains used are listed in Table 1. For the comparison of taxonomic characteristics, type strains of Flavobacterium 


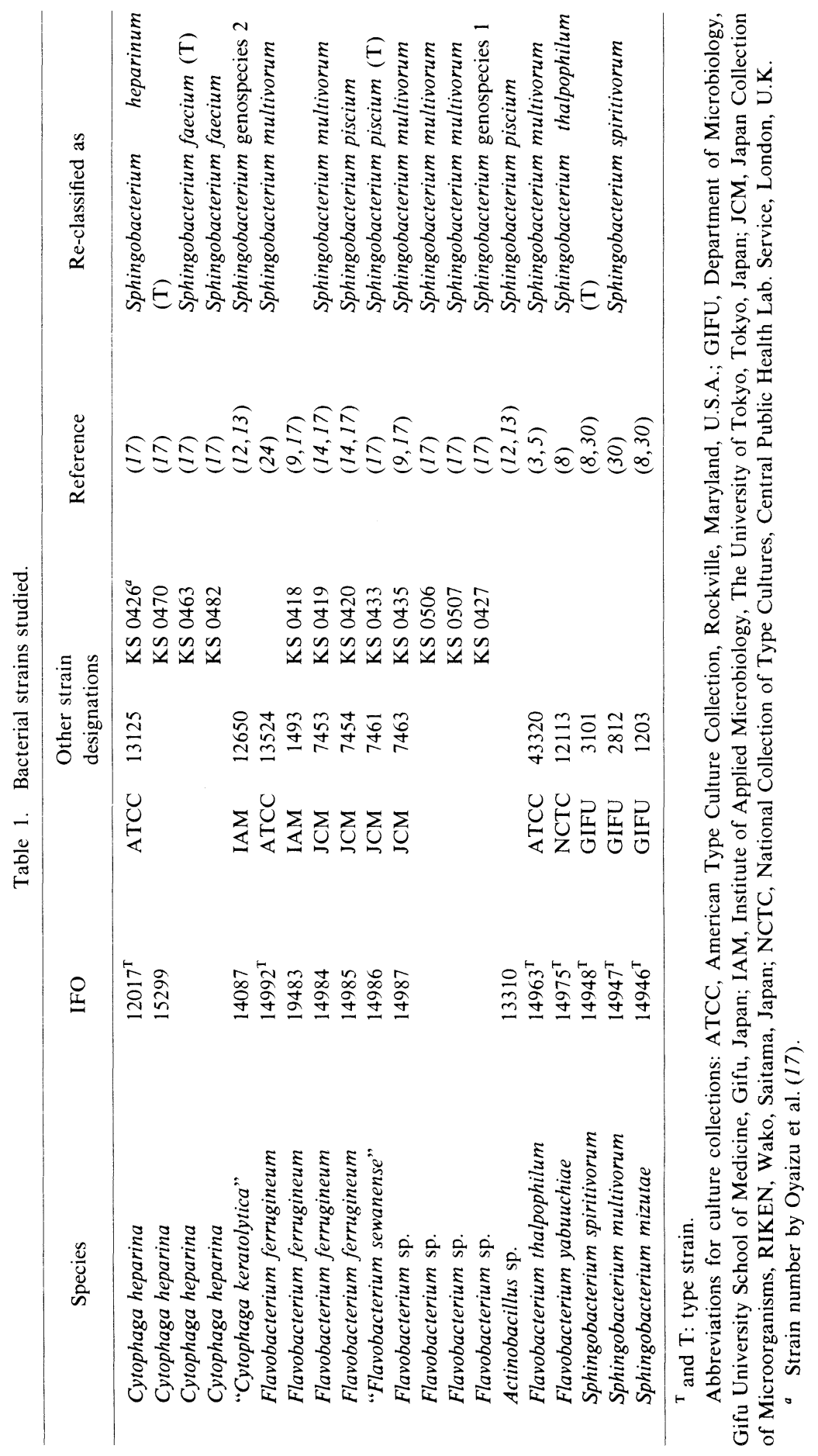


ferrugineum (24) and species of the genus Sphingobacterium were used. All strains were cultured at $28^{\circ} \mathrm{C}$ with aerobic shaking in PY medium containing $1 \%$ peptone, $0.2 \%$ yeast extract, $0.2 \% \mathrm{NaCl}$ and $0.2 \%$ glucose, $\mathrm{pH} 7.0$.

Determination of phenotypic characteristics. Cultures were grown on PY medium containing 1.5\% agar. API 20NE (Appareils et Procédés d'Identification; La Balme les Grottes, Montalieu Vercieu, France) was used for physiological and biochemical characteristics. API 50CH and API ZYM were used to determine the carbohydrate assimilation pattern and the enzymatic activities of test organisms. DNase test agar (Catalog No. 0632; Difco Lab., Detroit, Michigan, U.S.A.) was used for DNase activity.

Enzyme assay of endo- $\beta$-galactosidase. The reaction mixture contained $750 \mu \mathrm{g}$ of keratan sulfate (bovine cornea, Seikagaku Kogyo Co., Ltd., Tokyo, Japan) and an appropriate amount of the enzyme in $100 \mu \mathrm{l}$ of $0.05 \mathrm{M}$ sodium acetate buffer, $\mathrm{pH}$ 6.0. After incubation at $37^{\circ} \mathrm{C}$ for 5 to $30 \mathrm{~min}, 250 \mu \mathrm{l}$ of carbonate cyanide solution (13) was added to stop the reaction. An appropriate amount of the reaction mixture was then withdrawn and reducing sugars liberated were determined by the method of Park and Johnson (19).

Cellular lipids and fatty acid analysis. Cells harvested after culturing $24 \mathrm{~h}$ in PY medium were dried, mixed with $2 \mathrm{ml}$ of $5 \% \mathrm{HCl}$ in methanol and heated at 100 ${ }^{\circ} \mathrm{C}$ for $3 \mathrm{~h}$. Fatty acid methyl esters extracted with $n$-hexane/diethyl ether $(1: 1$, $\mathrm{v} / \mathrm{v}$ ) were separated by thin layer chromatography (TLC), extracted with diethyl ether, and analyzed by gas-liquid chromatography (GLC). The long-chain base components of the cellular sphingolipids were obtained from acid hydrolysates of dried cells by the method described by Yano et al. (31). The long-chain bases were developed by TLC, and their trimethylsilyl ether derivatives were analyzed by GLC and gas chromatography/mass spectrometry (GC-MS). GLC analyses were carried out using a GC-9A gas chromatograph (Shimadzu Corp., Kyoto, Japan). Columns employed were $10 \%$ diethyleneglycol succinate $(5 \mathrm{~m})$ at $180^{\circ} \mathrm{C}$ and $3 \% \mathrm{OV}-1(2 \mathrm{~m})$ at $165^{\circ} \mathrm{C}$ for fatty acid analysis and $3 \% \mathrm{OV}-1(2 \mathrm{~m})$ at $190^{\circ} \mathrm{C}$ for long-chain base analysis.

Abbreviations for fatty acids are as follows: In the shorthand numbering system used to identify fatty acids, the figures preceding the colon indicate the number of carbon atoms in the fatty acids, while those following the colon represent the number of double bonds present. $i$ indicates iso-branched acid.

DNA base composition. DNA was isolated by the method of Saito and Miura (22). G $+\mathrm{C}$ contents of DNAs were determined by reversed phase high-performance liquid chromatography $(\mathrm{HPLC})(15,27)$ after nuclease $\mathrm{P}_{1}$ and alkaline phosphatase treatment.

DNA/DNA hybridization. DNA/DNA hybridization was carried out by fluorometric hybridization in microdilution wells (4) using biotinylated DNA.

Quinone system. Isoprenoid quinone was extracted from the dried cells twice with chloroform/methanol $(2: 1, \mathrm{v} / \mathrm{v})$ for $4 \mathrm{~h}$ and analyzed by HPLC. HPLC was carried out using a Shimadzu liquid chromatograph LC-6AD with a Zorbax ODS 
$(4.6 \mathrm{~mm} \times 15 \mathrm{~cm})$ column. Menaquinone was detected by the absorbance at $270 \mathrm{~nm}$ using a Shimadzu spectrophotometric detector SPD-6A. Samples were eluted with methanol/isopropyl ether $(4: 1, \mathrm{v} / \mathrm{v})$ at $1 \mathrm{ml} / \mathrm{min}$ at $30^{\circ} \mathrm{C}$. The elution time and area of each peak were calculated with a Shimadzu Chromatopac C-R3A.

Sodium dodecyl sulfate-polyacrylamide gel electrophoresis (SDS-PAGE) analysis of whole cells. Wet cells $(0.1 \mathrm{~g})$ were suspended in $1.0 \mathrm{ml}$ of $0.0625 \mathrm{M}$ Tris- $\mathrm{HCl}$ buffer (pH 6.8) containing 2\% SDS, 5\% 2-mercaptoethanol and 10\% glycerol and heated at $100^{\circ} \mathrm{C}$ for $10 \mathrm{~min}(11)$. After centrifuging at $13,000 \times \mathrm{g}$ for $10 \mathrm{~min}$, the supernatant was subjected to electrophoresis. SDS-PAGE was performed in SDS-containing alkaline gel (10\%) using $0.025 \mathrm{M}$ Tris-glycine buffer ( $\mathrm{pH} 8.4$ ) containing $0.1 \%$ SDS at a constant current of $25 \mathrm{~mA}$. Proteins were visualized by staining in a stirred solution of Coomassie Blue.

\section{RESULTS}

\section{Morphological and physiological characteristics}

Phenotypic characteristics of 12 strains of phenovar " $4-5$ " have been reported by Oyaizu et al. (18). Their physiological and biochemical data agreed with our results derived from API 20NE, API 50CH and API ZYM system, except for acid production from some carbohydrates of $C$. heparina IFO $12017^{\mathrm{T}}$ (KS 0426). In our experiment, IFO $12017^{\mathrm{T}}$ did not produce acid from D-glucose, D-fructose, cellobiose, trehalose and glycerol but weakly produced acids from D-xylose and Larabinose, and these results were contrary to the results by Oyaizu et al. Data from API systems were taken in this paper.

All the strains studied were gram-negative rods, and colonies on nutrient agar after $48 \mathrm{~h}$ were circular, 1 to $3 \mathrm{~mm}$ in diameter, low convex, smooth and opaque. The color of the colonies on PY agar was creamy white. The tests for which all 19 strains except for $F$. ferrugineum IFO $14992^{\mathrm{T}}$ gave uniform results are summarized in Table 2.

\section{$G+C$ content of DNA and DNA $\mid D N A$ homology}

The $\mathrm{G}+\mathrm{C}$ contents of DNA of the strains except for $F$. ferrugineum IFO $14992^{\mathrm{T}}$ ranged from 39.0 to $42.5 \mathrm{~mol} \%$, while that of IFO $14992^{\mathrm{T}}$ was $48.4 \mathrm{~mol} \%$. As indicated by the data in Table 3, the strains studied could be separated into six distinct DNA relatedness groups. DNA/DNA homology values between $C$. heparina IFO $12017^{\mathrm{T}}$ and the other 18 strains were below $22 \%$. High homology values were obtained between $C$. heparina IFO 15299 and KS 0463 (group 2) and among Flavobacterium sp. KS 0427, F. ferrugineum IFO 14984 and IFO 14985 (group 3). On the other hand, DNA/DNA homology velues among " $C$. keratolytica" IFO 14087, F. ferrugineum IFO 14983, Flavobacterium sp. KS 0506 and IFO 14987, " $F$. sewanense" IFO 14986, Actinobacillus sp. IFO 13310 and S. multivorum IFO $14947^{\mathrm{T}}$ were 30 to $76 \%$, but the values between these 7 strains and strains of other groups were low $(0$ to $30 \%$ ). Based on the results of DNA/DNA hybridization, these 7 
Table 2. Tests for which all 19 strains gave positive or negative results.

\begin{tabular}{|c|c|}
\hline Positive results & Negative results \\
\hline $\begin{array}{l}\text { Catalase production } \\
\text { Oxidase production } \\
\text { Enzymatic activity (API ZYM) } \\
\text { Alkaline phosphatase } \\
\text { Esterase lipase }\left(\mathrm{C}_{8}\right) \\
\text { Acid phosphatase } \\
\text { Naphthol-AS-B1-phosphohydrase } \\
\text { Leucine arylamidase } \\
\beta \text {-Galactosidase } \\
N \text {-Acetyl- } \beta \text {-glucosaminidase } \\
\beta \text {-Glucosidase } \\
\text { Esterase }\left(\mathrm{C}_{4}\right) \\
\text { Cystine arylamidase } \\
\alpha \text {-Glucosidase } \\
\alpha \text {-Mannosidase } \\
\text { Acid production }(\mathrm{API} 50 \mathrm{CH}) \\
\text { Galactose } \\
\text { Glucose } \\
\text { D-Fucose } \\
\text { Mannose } \\
\text { Esculin } \\
\text { Cellobiose } \\
\text { Maltose } \\
\text { Lactose } \\
\text { Saccharose } \\
\text { D-Turanose }\end{array}$ & $\begin{array}{l}\text { Indole production } \\
\text { Acid production } \\
\text { D-Fucose } \\
\text { Gluconate } \\
\text { 2-Keto-gluconate } \\
\text { Erythritol } \\
\text { L-Xylose } \\
\text { Adonitol } \\
\text { Dulcitol } \\
\text { Inositol } \\
\text { L-Arabitol } \\
\text { D-Tagatose }\end{array}$ \\
\hline
\end{tabular}

strains are considered to be included in the same DNA/DNA homology group (group 4). Flavobacterium sp. KS 0507 (group 5) and C. heparina KS 0482 (group 6) did not show homology with any other strains tested.

\section{Chemotaxonomic characteristics}

As shown in Table 4, all 20 strains contained menaquinone 7, and all except $F$. ferrugineum IFO $14992^{\mathrm{T}}$ contained relatively large amounts of long-chain bases, one of which was identified as dihydrosphingosin (d17:0) by GC-MS analysis. It showed a characteristic molecular mass of $m / z$ 73, 116, 132, 234, 299, 326, 328, 416 and 431. Keratan sulfate-degrading enzyme (endo- $\beta$-galactosidase) activity was detected in group 4 strains: " $C$. keratolytica" IFO 14087, " $F$. sewanense" IFO 14986, Flavobacterium sp. IFO 14987 and Actinobacillus sp. IFO 13310. This activity was not found in the strains of other DNA/DNA homology groups. As shown in Table 4, all strains except for $C$. heparina IFO $12017^{\mathrm{T}}$ and $F$. ferrugineum IFO $14992^{\mathrm{T}}$ contained $i-15: 0$ and 16:1 (9) fatty acids as major components. $C$. heparina IFO $12017^{\mathrm{T}}$ contained $i-15: 0$ and $17: 0$ as the major components of cellular acids, but the other 19 strains did not contain $17: 0$. In the strain IFO $14992^{\mathrm{T}}, 14: 0$ and $i-15: 0$ were the major fatty acids. As hydroxy fatty acids, all the 


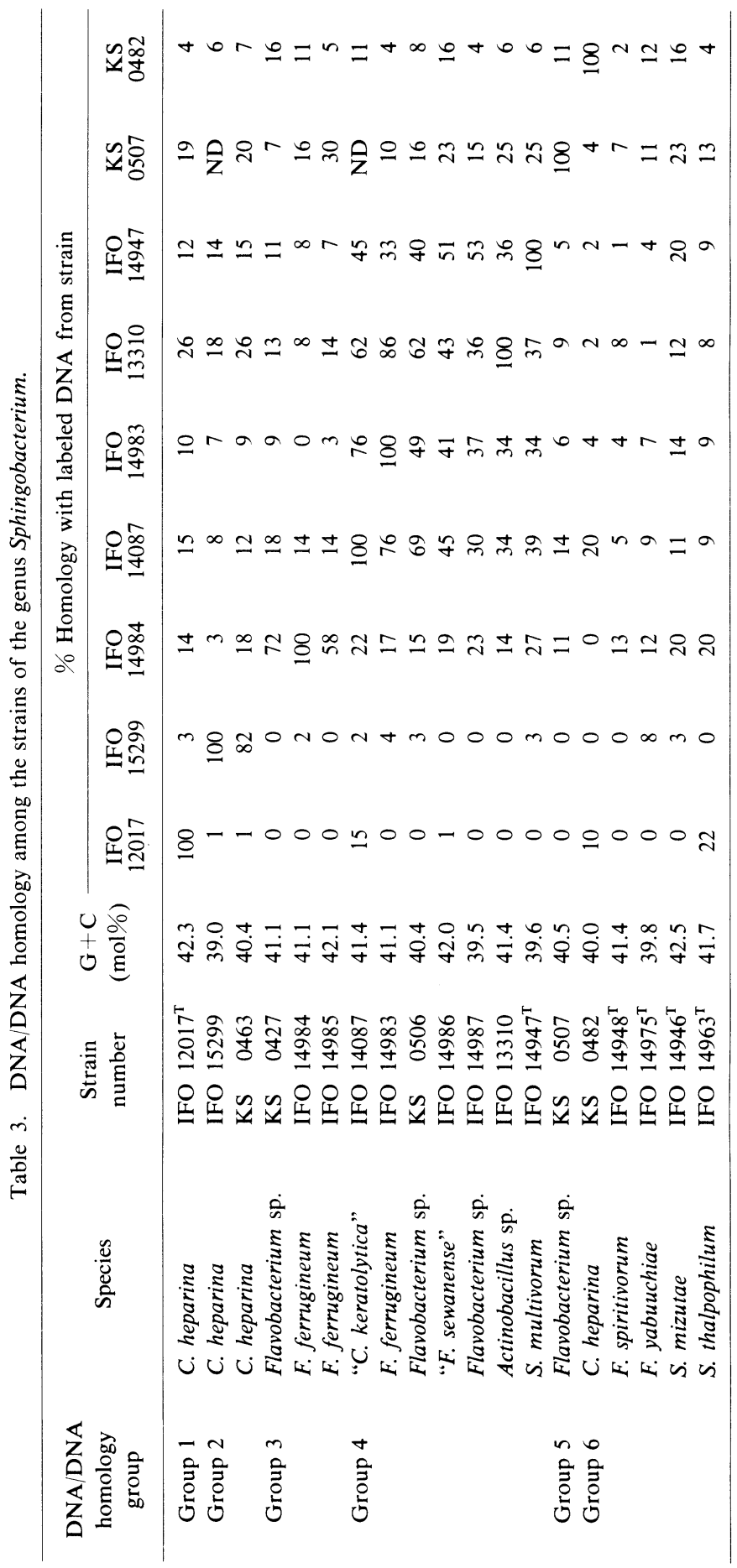




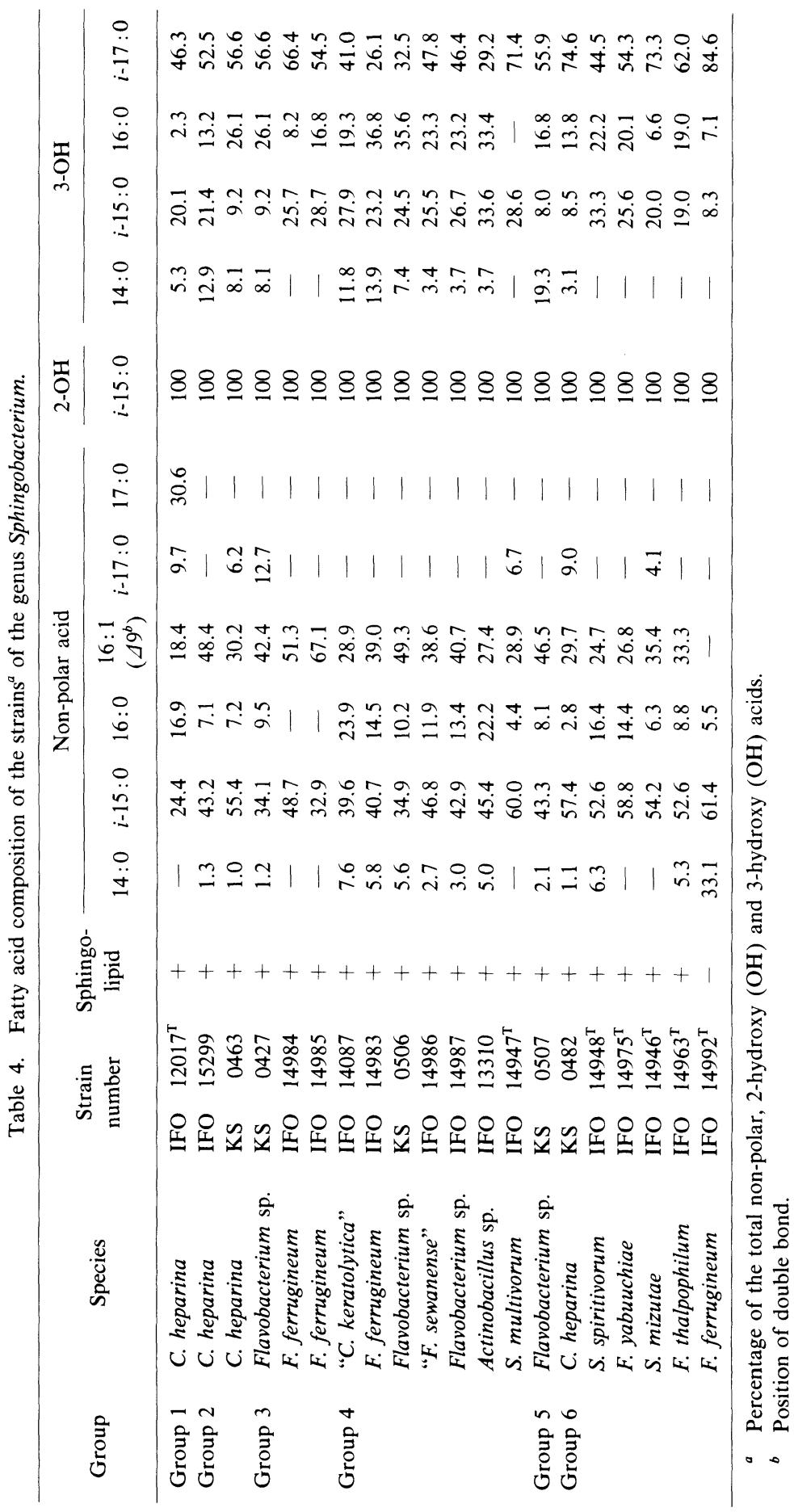




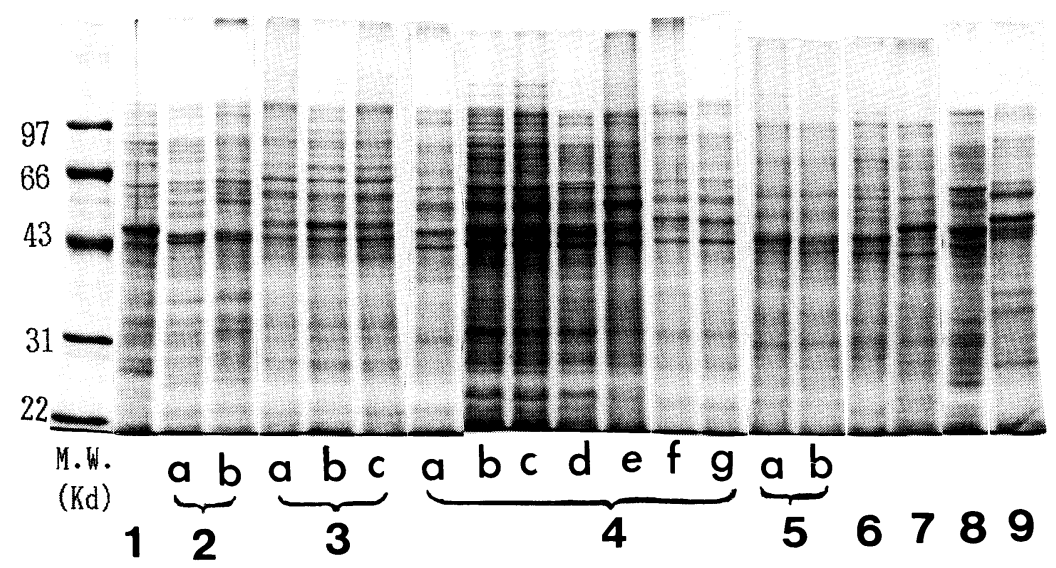

Fig. 1. SDS-PAGE of the whole-cell proteins of the genus Sphingobacterium.

Lanes: 1, (group 1) IFO 12017 ${ }^{\mathrm{T}}$; 2, (group 2) (a, IFO 15299, b, KS 0463); 3, (group 3) (a, KS 0427, b, IFO 14984, c, IFO 14985); 4, (group 4) (a, IFO 14087, b, IFO 14986, c, IFO 14987, d, IFO 13310, e, IFO 14947 ${ }^{\mathrm{T}}$, f, IFO 14983, g, KS 0506); 5, $\left(\mathrm{a}\right.$, IFO $14975^{\mathrm{T}}$, b, IFO $14948^{\mathrm{T}}$ ); 6, IFO $14946^{\mathrm{T}}$; 7, IFO $14963^{\mathrm{T}} ; 8$, (group 5) KS 0507; 9, (group 6) KS 0482.

strains contained 2-hydroxy $i-15: 0,3$-hydroxy $i-15: 0$ and 3-hydroxy $i-17: 0$.

\section{Whole-cell SDS-PAGE protein pattern}

Comparison of the whole-cell protein pattern revealed that the strains belonging to the same DNA relatedness group showed similar patterns (Fig. 1). Strains of DNA relatedness group 4 also showed high similarity in this pattern. The whole-cell protein patterns of $F$. yabuuchiae IFO $14975^{\mathrm{T}}$ and $S$. spiritivorum IFO $14948^{\mathrm{T}}$ were found to be quite similar.

\section{Phenotypic differentiation}

The results presented above indicated that the 6 DNA relatedness groups constitute separate taxa. Differential characteristics among the 6 groups and the 4 previously-known species of the genus Sphingobacterium are summarized in Table 5. C. heparina IFO $12017^{\mathrm{T}}$ was clearly differentiated from the other 19 strains in many physiological characteristics, especially the ability to produce acid from carbohydrates which is very weak or negative. The biochemical characteristics of F. spiritivorum IFO $14948^{\mathrm{T}}$ are very similar to those of $F$. yabuuchiae IFO $14975^{\mathrm{T}}$.

\section{DISCUSSION}

In Bergey's Manual of Systematic Bacteriology, Vol. 1(6), Holmes et al. describe the genus Flavobacterium as historically and taxonomically heterogeneous. The wide range of $\mathrm{G}+\mathrm{C}$ content of DNA between 30 to $45 \mathrm{~mol} \%$ suggests that the 


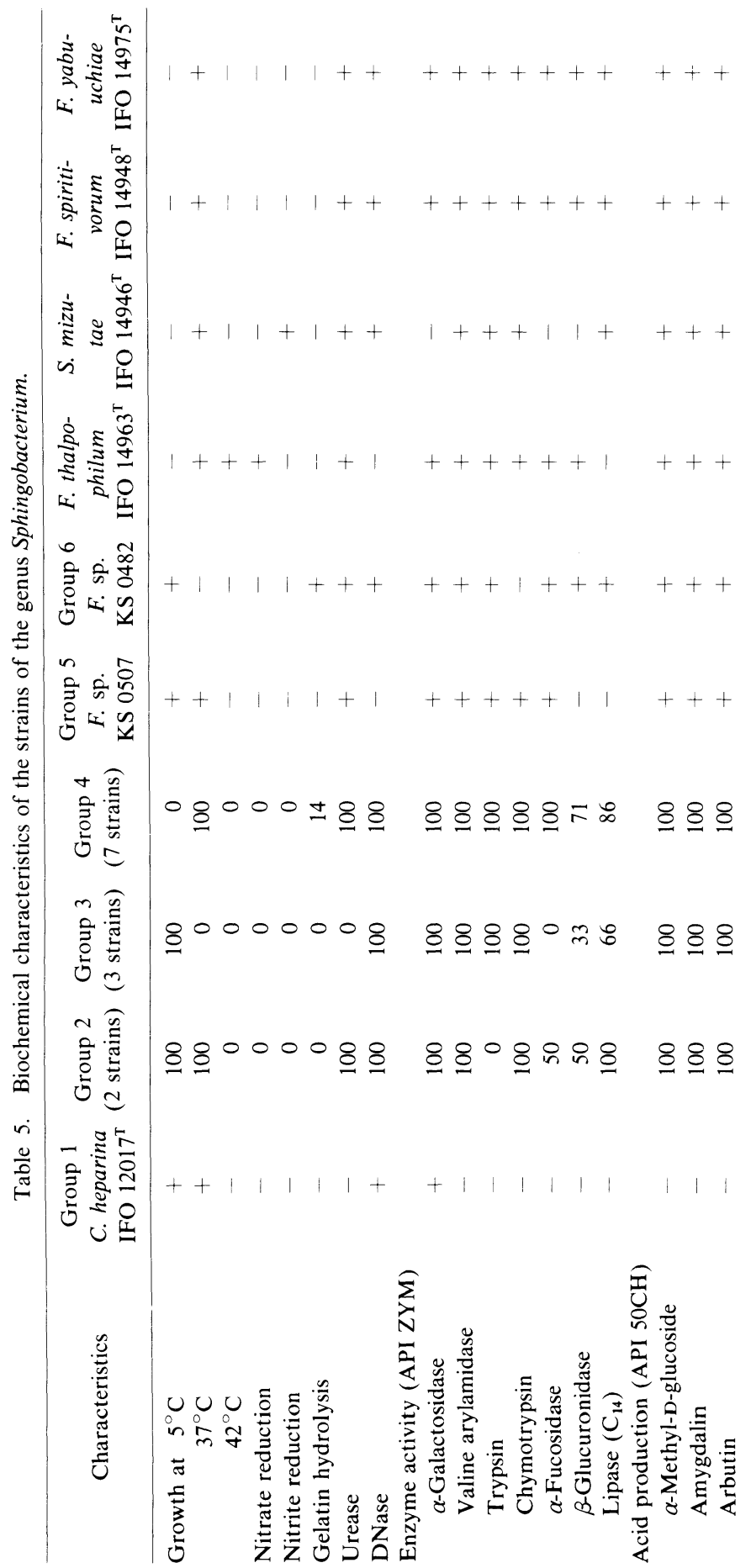




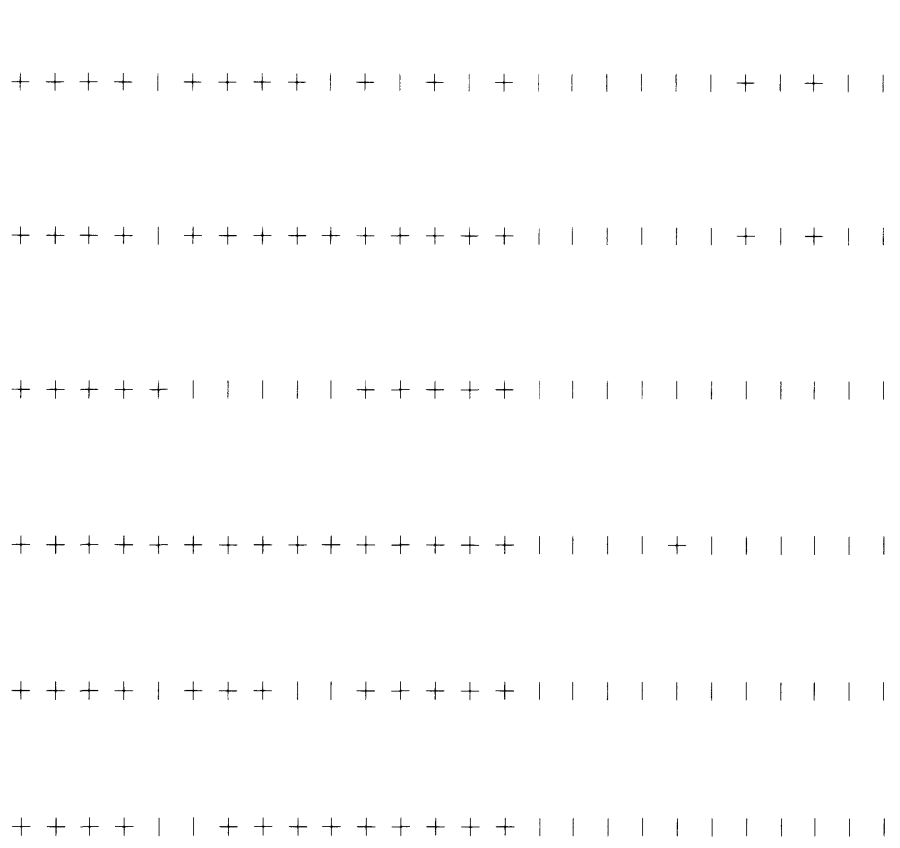

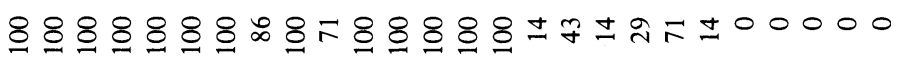

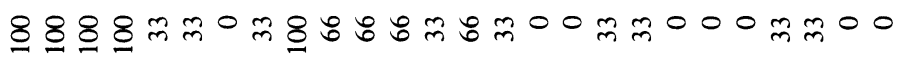

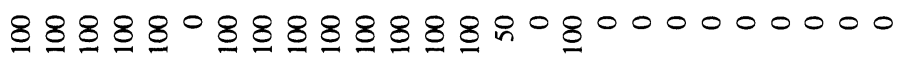

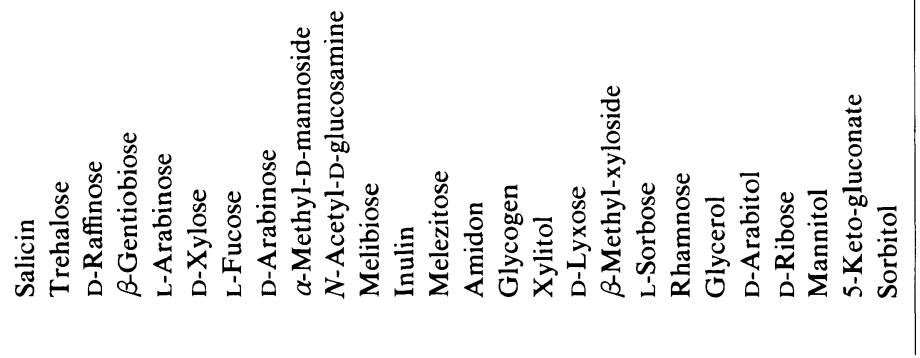


genus is heterogeneous. $\mathrm{G}+\mathrm{C}$ content of the strains of the genus Flavobacterium are around $34 \mathrm{~mol} \%$, and the species which have $\mathrm{G}+\mathrm{C}$ content of DNA higher than $39 \mathrm{~mol} \%$ should be set apart from the genus Flavobacterium. On the other hand, the respiratory quinone pattern appears to be particularly useful for the purpose of subdividing the genus Flavobacterium $(1,17)$. The menaquinone system of the strains belonging to the genus Flavobacterium is MK-6, and strains with MK7 can be excluded from the genus Flavobacterium. Yabuuchi et al. proposed the new genus Sphingobacterium for the strains named Flavobacterium having approximately 39 to $42 \mathrm{~mol} \% \mathrm{G}+\mathrm{C}$ contents of DNA, isoprenoid quinones with MK-7 and sphingolipids with the long-chain base dihydrosphingosin, which are absent in other Flavobacterium species (30).

In this paper, we characterized 17 strains of Cytophaga and Flavobacterium. On the basis of the characteristics described above, all the strains studied were identified as organisms belonging to the genus Sphingobacterium, and were divided into 6 DNA homology groups. Each DNA relatedness group except for group 4, differed from previously-known species of this genus. Based on these DNA/DNA hybridization studies and the chemotaxonomic and physiological characteristics, we propose two new species, $S$. faecium for the group 2 strains and $S$. piscium for the group 3 strains, a new combination, $S$. heparinum, for the group 1 strain and two genospecies for group 5 and 6 strains. Strains of group 5 and 6 are genotypically distinct but are difficult to phenotypically differentiate from alreadyknown species and other groups, and furthermore, only one strain was detected in the respective group until now. Therefore, we were reluctant to propose new species for these strains. We also propose transferring $F$. thalpophilum to the genus Sphingobacterium as a species of a new combination, $S$. thalpophilum. Differential characteristics among the species and two genospecies are listed in Table 6.

The new species $S$. antarcticus, recently proposed by Shivaji et al. (23), grows between 2 and $30^{\circ} \mathrm{C}$ and not at temperatures above $30^{\circ} \mathrm{C}$. Strains of S. piscium grow at $5^{\circ} \mathrm{C}$ and not at $37^{\circ} \mathrm{C}$. However, as shown in Table $6, S$. antarcticus differs from $S$. piscium and other Sphingobacterium species in many physiological characteristics.

Steyn et al. (25) have recently reported the taxonomic relationship of heparinase-producing strains including the type strain of $C$. heparina. Their DNA/rRNA hybridization studies revealed that these isolates display considerable genotypic and phenotypic heterogeneity, and were divided into three rRNA similarity groups. They suggested that these strains probably constitute a separate genus from Sphingobacterium, Flavobacterium and Cytophaga because of $\operatorname{Tm}(e)$ of more than $7^{\circ} \mathrm{C}$ and separate protein electrophoretic profiles. However, we consider that $C$. heparina should be placed in the genus Sphingobacterium because of the homogeneity in morphological, physiological and chemotaxonomic characteristics among the strains mentioned above and already-known species of the genus Sphingobacterium. Much additional work, including analysis of 16S rRNA sequences between $S$. heparina and representatives of Sphingobacterium species, will be necessary to 


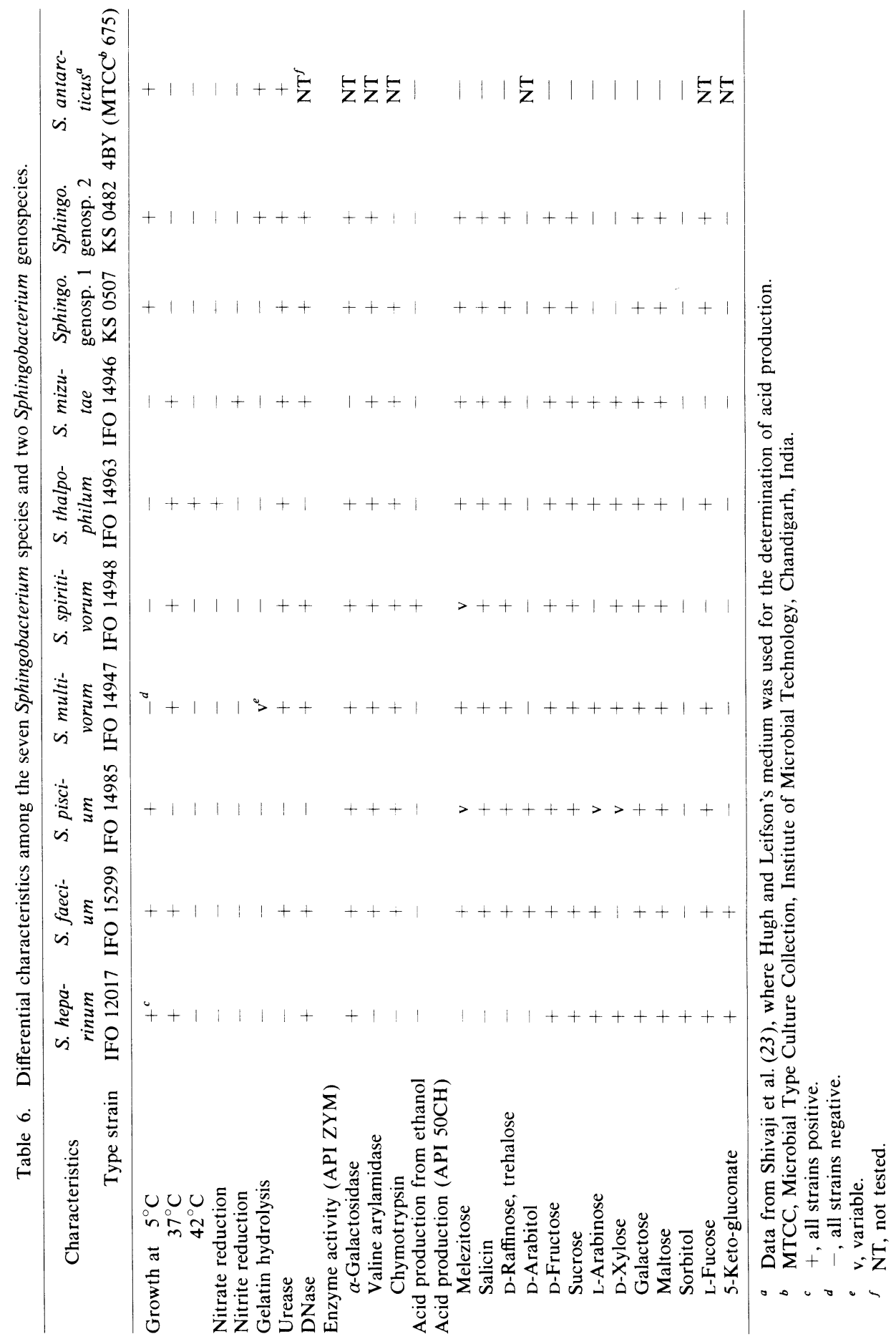


determine the relationship of this new species with respect to existing species of the Flavobacterium-Cytophaga-Sphingobacterium group.

In addition, chemotaxonomic data presented here and their DNA/rRNA hybridization studies (25) indicate that the type strain of $F$. ferrugineum probably constitutes a separate genus.

Holmes et al. (8) reported that $F$. yabuuchiae does not hydrolyze 2-naphthyl phosphate at $\mathrm{pH}$ 5.4, and this characteristic differentiates $F$. yabuuchiae from $F$. spiritivorum and other Sphingobacterium species, despite the high homology value of DNA/DNA hybridization (63\%) between them. However, in our experiment, type strains of both species hydrolyzed 2-naphtyl phosphate at $\mathrm{pH} 5.4$, and the two strains showed high similarity in whole-cell protein pattern in SDS-PAGE and physiological characteristics. Based on these results, we conclude that these two species are the same species, and therefore, $F$. yabuuchiae should be included in $S$. spiritivorum.

The re-classification of test strains is summarized in Table 1. Descriptions for the new species, new combination and new genospecies are given below.

Description of Sphingobacterium faecium sp. nov.

Sphingobacterium faecium (fae'ci.um. L. n. faecis, dregs; L. gen. pl. n. faecium, of the dregs, of feces) cells are gram-negative, nonsporing rods $0.4-0.5 \times 0.5-1.0$ $\mu \mathrm{m}$. Nonmotile, nongliding (no sliding translocation occurs). Aerobic. Circular, entire, low convex, smooth and opaque colonies developing on nutrient agar after 2 days; on nutrient agar, a yellow or creamy white, nonfluorescent pigment is produced. Grows at $5^{\circ} \mathrm{C}$ and $37^{\circ} \mathrm{C}$ but not at $42^{\circ} \mathrm{C}$. Catalase, oxidase, urease, extracellular deoxyribonuclease and phosphatase (alkaline and acid) are produced, but gelatinase is not produced. Indole is not produced. Esculin is hydrolyzed. Nitrate and nitrite are not reduced. D-Xylose, L-arabinose, D-glucose, D-fructose, cellobiose, maltose, sucrose, raffinose, starch and inulin are utilized. Heparin, succinoglucan, pectin, polypectate, cellulose, arginate, chitin and agar are not utilized. Acid is produced from salicin, trehalose, raffinose, D- and L-arabinose, L-fucose, inulin, melibiose and melezitose but not from L-xylose, sorbose, rhamnose, xylitol, mannitol, D-ribose or ethanol (3\%). $\beta$-Glucosidase and valine arylamidase are produced but trypsin and $\beta$-glucuronidase are not. $\mathrm{G}+\mathrm{C}$ content of DNA is 39.0 to $40.4 \mathrm{~mol} \%$. The major isoprenoid quinone is MK-7. The major non-polar fatty acids from whole cells are $i-15: 0$ and $16: 1$ and 2-hydroxy $i-15: 0$, 3-hydroxy $i-15: 0$ and 3-hydroxy $i-17: 0$.

The type strain is IFO 15299 (KS 0470).

Description of Sphingobacterium piscium sp. nov.

Sphingobacterium piscium (pis'ci.um. L. n. piscis, a fish; L. gen. pl. piscium, of fishes) cells are gram-negative, nonsporing rods $0.4-0.5 \times 0.5-1.0 \mu \mathrm{m}$. Nonmotile, nongliding (no sliding translocation occurs). Aerobic. Circular, entire, low convex, smooth and opaque colonies developing on nutrient agar after 2 days; on nutrient 
agar, a yellow or creamy white, nonfluorescent pigment is produced. Grows at 5 ${ }^{\circ} \mathrm{C}$ but not at $37^{\circ} \mathrm{C}$ or $42^{\circ} \mathrm{C}$. Catalase, oxidase, extracellular deoxyribonuclease and phosphatase (alkaline and acid) are produced, but gelatinase and urease are not. Indole is not produced. Esculin is hydrolyzed. Nitrate and nitrite are not reduced. D-Xylose, L-arabinose, D-glucose, D-fructose, cellobiose, maltose, sucrose, raffinose and inulin are not utilized. Acid is produced from salicin, trehalose and D-raffinose but not from L-fucose, D- and L-arabinose, melezitose or ethanol (3\%). Esterase, valine arylamidase, trypsin and chymotrypsin are produced; $\alpha$-galactosidase, $\alpha$ fucosidase and $\beta$-glucuronidase are not. $\mathrm{G}+\mathrm{C}$ content of DNA is 41.1 to $42.1 \mathrm{~mol}$ $\%$. The major isoprenoid quinone is MK-7. The major non-polar fatty acids from whole cells are $i-15: 0$ and 16:1 and 2-hydroxy $i-15: 0,3$-hydroxy $i-15: 0$ and 3hydroxy $i-17: 0$.

The type strain is IFO 14985 (JCM 7454).

Description of Sphingobacterium heparinum (Christensen) comb. nov.

Sphingobacterium heparinum (he.pa.ri'num. Gr. n. hepar, liver; M. L. neut. adj. heparinum, connected with degrading heparin, acidic mucoheteropolysaccharides with sulfate groups from various animal tissues) cells are gram-negative, nonsporing rods $0.4-0.5 \times 0.5-1.0 \mu \mathrm{m}$. Nonmotile, nongliding (no sliding translocation occurs). Aerobic. Circular, entire, low convex, smooth and opaque colonies developing on nutrient agar after 2 days; on nutrient agar, a yellow or creamy white, nonfluorescent pigment is produced. Grows at $5^{\circ} \mathrm{C}$ and at $37^{\circ} \mathrm{C}$ but not at $42^{\circ} \mathrm{C}$. Catalase, oxidase, extracellular deoxyribonuclease and phosphatase (alkaline and acid) are produced, but gelatinase and urease are not. Indole is not produced. Esculin is hydrolyzed. Nitrate and nitrite are not reduced. D-Xylose, L-arabinose, D-glucose, D-fructose, cellobiose, maltose, sucrose, raffinose, starch and inulin, heparin and polypectate are utilized. Succinoglucan, pectin, cellulose, chitin and agar are not utilized. Acid is produced from D-xylose, L-fucose, 5keto-gluconate and sorbitol but not from $\mathrm{D}$ - and L-arabinose, salicin, trehalose and D-raffinose, inulin, xylitol, melezitose, mannitol, D-ribose or ethanol (3\%). $\beta$ Glucosidase, esterase $\left(\mathrm{C}_{4}\right)$ and $\alpha$-galactosidase are produced, but cystine arylamidase, valine arylamidase, trypsin, chymotrypsin, $\beta$-glucuronidase and lipase $\left(\mathrm{C}_{14}\right)$ are produced. $\mathrm{G}+\mathrm{C}$ content of $\mathrm{DNA}$ is $42.3 \mathrm{~mol} \%$. The major isoprenoid quinone is MK-7. The major non-polar fatty acids from whole cells are $i-15: 0$, $16: 0,16: 1, i-17: 0$ and $17: 0$ and 2-hydroxy $i-15: 0,3$-hydroxy $i-15: 0$ and $3-$ hydroxy $i-17: 0$.

The type strain is IFO 12017 (ATCC 13125).

Description of Sphingobacterium thalpophilum (Holmes) comb. nov.

Sphingobacterium thalpophilum (thal.po'phi.lum. Gr. n. thalps, warmth; Gr. n. adj. philon, loving; M. L. n. adj. thalpophilum, warmth-loving) cells are gramnegative, nonsporing rods $0.4-0.5 \times 0.5-1.0 \mu \mathrm{m}$. Nonmotile, nongliding (no sliding translocation occurs). Aerobic. Circular, entire, low convex, smooth and opaque 
colonies developing on nutrient agar after 2 days; on nutrient agar, a yellow or creamy white, nonfluorescent pigment is produced. Grows at $37^{\circ} \mathrm{C}$ but not at $5^{\circ} \mathrm{C}$ or $42^{\circ} \mathrm{C}$. Catalase, oxidase, urease and phosphatase (alkaline and acid) are produced, but gelatinase and extracellular deoxyribonuclease are not. Indole is not produced. Esculin is hydrolyzed. Nitrate is reduced to nitrite, but nitrite is not reduced. D-Xylose, L-arabinose, D-glucose, D-fructose, cellobiose, maltose, sucrose, raffinose, starch and inulin are utilized, but heparin is not utilized. Acid is produced from salicin, L-fucose, trehalose, inulin, D-raffinose, D- and L-arabinose and rhamnose but not from L-lyxose, sorbose, xylitol, mannitol, D-ribose or ethanol (3\%). $\beta$-Glucosidase, esterase $\left(\mathrm{C}_{4}\right)$, cystine arylamidase, valine arylamidase, $\alpha$ mannosidase and $\alpha$-fucosidase are produced, but chymotrypsin, $\beta$-glucuronidase and lipase $\left(\mathrm{C}_{14}\right)$ are not. $\mathrm{G}+\mathrm{C}$ content of $\mathrm{DNA}$ is $41.7 \mathrm{~mol} \%$. The major isoprenoid quinone is MK-7. The major non-polar fatty acids from whole cells are $i-15: 0$ and $16: 1$ and 2-hydroxy $i-15: 0,3$-hydroxy $i-15: 0$ and 3-hydroxy $i-17: 0$.

The type strain is IFO 14963 (ATCC 43320).

\section{Description of Sphingobacterium genospecies 1 and 2}

Two strains, KS 0507 and KS 0482, are assigned to genospecies 1 and 2, respectively. Cells are all gram-negative, nonsporing rods $0.4-0.5 \times 0.5-1.0 \mu \mathrm{m}$. Nonmotile, nongliding (no sliding translocation occurs). Aerobic. Circular, entire, low convex, smooth and opaque colonies developing on nutrient agar after 2 days; on nutrient agar, a yellow or creamy white, nonfluorescent pigment is produced, and possess all of the characteristics of the genus Sphingobacterium. The strain of genospecies 1, KS 0507, does not utilize D-xylose, L-arabinose, D-glucose, Dfructose, cellobiose, maltose, sucrose, raffinose, starch or inulin, but the strain of genospecies 2, KS 0482, does, and they do not utilize heparin, succinoglucan, pectin, polypectate, cellulose, chitin or agar. Both genospecies are positive for acid production from $\alpha$-methyl-D-glucoside, amygdalin, arbutin, salicin, trehalose, $\beta$ gentiobiose, D- and L-arabinose, L-fucose, melibiose, melezitose, starch and glycogen but not xylitol, rhamnose, L-sorbose, mannitol or D-ribose. Both produced $\beta$-glucosidase, esterase $\left(\mathrm{C}_{4}\right)$, cystine arylamidase, $\alpha$-mannosidase and $\alpha$-fucosidase. KS 0482 produces $\alpha$-galactosidase, valine arylamidase and $\beta$-glucuronidase, but KS 0507 does not. G + C content of DNA of KS 0507 and KS 0482 is 40.5 and 40.0 mol\%, respectively. The major isoprenoid quinone is MK-7. The major non-polar fatty acids from whole cells are $i-15: 0$ and 16:1 and 2-hydroxy $i-15: 0,3$-hydroxy $i-15: 0$ and 3-hydroxy $i-17: 0$.

The authors thank Dr. K. Komagata, Prof. of Tokyo Univ. of Agric., and Dr. J. Sugiyama, Prof. of Inst. Appl. Microbiol., The Univ. Tokyo, for supplying the bacterial strains and also express their deep gratitude to Dr. T. Hasegawa, Director of this institute, for his encouragement and support. 


\section{REFERENCES}

1) Callies, E. and Mannheim, W., Classification of the Flavobacterium-Cytophaga complex on the basis of respiratory quinones and fumarate respiration. Int. J. Syst. Bacteriol., 28, 14-19 (1978).

2) Christensen, P., Description and taxonomic status of Cytophaga heparina (Payza and Korn) comb. nov. (Basionym: Flavobacterium heparinum Payza and Korn 1956). Int. J. Syst. Bacteriol., 30, 473-475 (1980).

3) Dees, S. B., Carlone, G. M., Hollis, D., and Moss, C. W., Chemical and phenotypic characteristics of Flavobacterium thalpophilum compared with those of other Flavobacterium and Sphingobacterium species. Int. J. Syst. Bacteriol., 35, 16-22 (1985).

4) Ezaki, T., Hashimoto, Y., and Yabuuchi, E., Fluorometric deoxyribonucleic acid-deoxyribonucleic acid hybridization in microdilution wells as an alternative to membrane filter hybridization in which radioisotopes are used to determine genetic relatedness among bacterial strains. Int. J. Syst. Bacteriol., 39, 224-229 (1989).

5) Holmes, B., Holmes, D. G., Steigerwalt, A. G., Pickett, M. J., and Brenner, D. J., Flavobacterium thalpophilum, a new species recovered from human clinical material. Int. J. Syst. Bacteriol., 33, 677-682 (1983).

6) Holmes, B., Owen, J., and McMeekin, A., Genus Flavobacterium Bergey, Harrison, Breed, Hammer and Huntoon 1923, 97 ${ }^{\mathrm{AL}}$. In Bergey's Manual of Systematic Bacteriology, Vol. 1, ed. by Krieg, N. R. and Holt, J. G., The Williams \& Wilkins Co., Baltimore (1984), p. 353-361.

7) Holmes, B., Owen, J. G., Steigerwalt, A. G., and Brenner, D. J., Flavobacterium gleum, a new species found in human clinical specimens. Int. J. Syst. Bacteriol., 34, 21-25 (1984).

8) Holmes, B., Weaver, R. E., Steigerwalt, A. G., and Brenner, D. J., A taxonomic study of Flavobacterium spiritivorum and Sphingobacterium mizutae: proposal of Flavobacterium yabuuchiae sp. nov. and Flavobacterium mizutaii comb. nov. Int. J. Syst. Bacteriol., 38, 348-353 (1988).

9) Iizuka, H. and Komagata, K., Microbiological studies on petroleum and natural gas. I. Determination of hydrocarbon-utilizing bacteria. J. Gen. Appl. Microbiol., 10, $207-221$ (1964).

10) Imai, K., Descriptive catalogue of IFO bacterial collection VII. 72. Cytophaga keratolytica. IFO Res. Comm., 12, 120-121 (1985).

11) Kerster, K., Numerical methods in classification of bacteria by protein electrophoresis. In Computer-assisted Bacterial Systematics, ed. by Goodfellow, M., Jones, D., and Priest, F. G., Academic Press Ltd., London (1985), p. 337-368.

12) Kitamikado, M. and Ito, M., Isolation of keratanase-producing bacteria from natural habitats. $J$. Fac. Agric. Kyushu Univ., 24, 101-112 (1979).

13) Kitamikado, M., Ito, M., and Li, Yu-Teh, Isolation and characterization of a keratan sulfatedegrading endo- $\beta$-galactosides from Flavobacterium keratolyticus. J. Biol. Chem., 256, 3906-3909 (1981).

14) Komagata, K. and Ogawa, H., Microbiological studies on foods. III. Determination of gramnegative bacteria isolated from frozen foods. Shokuhin Eiseigaku Zasshi, 7, 239-247 (1966) (in Japanese).

15) Mesbah, M., Premachandran, U., and Whitman, W. B., Precise measurement of the G + C content of deoxyribonucleic acid by high-performance liquid chromatography. Int. J. Syst. Bacteriol., 39, 159-167 (1989).

16) Nakazawa, M., Suzuki, N., and Suzuki, S., Sequential degradation of keratan sulfate by bacterial enzymes and purification of sulfatase in the enzymatic system. J. Biol. Chem., 250, 905-911 (1975).

17) Oyaizu, H. and Komagata, K., Chemotaxonomic and phenotypic characterization of the strains of species in the Flavobacterium-Cytophaga complex. J. Gen. Appl. Microbiol., 27, 57-107 (1981).

18) Oyaizu, H., Komagata, K., Amemura, A., and Harada, T., A succinoglycan-decomposing bacte- 
rium, Cytophaga arvensicola sp. nov. J. Gen. Appl. Microbiol., 28, 369-388 (1982).

19) Park, J. T. and Johnson, M. J., A submicrodetermination of glucose. J. Biol. Chem., 181, 149-151 (1949).

20) Payza, A. H. and Korn, E. D., Bacterial degradation of heparin. Nature (London), 166, 88-89 (1956).

21) Reichenbach, H., Genus I. Cytophaga Winogradsky 1929, 577 ${ }^{\mathrm{AL}}$, emend. In Bergey's Manual of Systematic Bacteriology, Vol. 3, ed. by Staley, J. T., Bryant, M. P., Pfennig, N., and Holt, J. G., The Williams \& Wilkins Co., Baltimore (1989), p. 2015-2050.

22) Saito, H. and Miura, K., Preparation of transforming deoxyribonucleic acid by phenol treatment. Biochim. Biophys. Acta, 72, 619-629 (1963).

23) Shivaji, S., Ray, M. K., Shyamale Rao, N., Saisree, L., Jagannadham, V., Seshu Kumar, G., Reddy, G. S., and Bhargava, P. M., Sphingobacterium antarcticus sp. nov., a psychrotrophic bacterium from the soil of Schirmacher Oasis, Antarctica. Int. J. Syst. Bacteriol., 42, 102-106 (1992).

24) Sickles, G. M. and Shaw, M., A systematic study of microorganisms which decompose the specific carbohydrates of the pneumococcus. J. Bacteriol., 28, 415-431 (1934).

25) Steyn, P. L., Pot, B., Sogers, P., Kersters, K., and Joubert, J., Some novel aerobic heparindegrading bacterial isolates. System. Appl. Microbiol., 15, 137-143 (1992).

26) Takeuchi, M. and Yokota, A., Reclassification of strains of Flavobacterium-Cytophaga group in IFO culture collection. IFO Res. Commun., 15, 83-96 (1991).

27) Tamaoka, J. and Komagata, K., Determination of DNA base composition by reverse-phase high-performance liquid chromatography. FEMS Microbiol. Lett., 25, 125-128 (1984).

28) Wakabayashi, H., Huh, G. J., and Kimura, J., Flavobacterium branchiophila sp. nov., a causative agent of bacterial gill disease of freshwater fishes. Int. J. Syst. Bacteriol., 39, 213-216 (1989).

29) Winogradsky, S., Etudes sur la microbiologie du dol. Sur la degradation de la cellulose dans le sol. Ann. Inst. Pasteur (Paris), 43, 549-633 (1929).

30) Yabuuchi, E., Kaneko, T., Yano, I., Moss, W., and Miyoshi, N., Sphingobacterium gen. nov., Sphingobacterium spiritivorum comb. nov., Sphingobacterium multivorum comb. nov., Sphingobacterium mizutae sp. nov., and Flavobacterium indologenes sp. nov.: glucose-nonfermenting gramnegative rods in CDC group IIK-2 and IIb. Int. J. Syst. Bacteriol., 33, 580-598 (1983).

31) Yano, I., Tomiyasu, I., and Yabuuchi, E., Long chain base composition of strains of three species of Sphingobacterium gen. nov. FEMS Microbiol. Lett., 15, 303-307 (1982). 